\title{
Folate binders in body fluids
}

\author{
F. P. RETIEF ${ }^{1}$ AND YVONNE J. HUSKISSON \\ From the Haematology Division, Department of Internal Medicine, Stellenbosch University \\ Medical School, Bellville, CP, Republic of South Africa
}

SYNOPSIS In normal serum, saline dialysis for 48 hours in Visking casing resulted in folate clearance closely comparable to that produced by haemoglobin-coated charcoal adsorption, except in kwashiorkor where charcoal removed a greater proportion of folate. Pre- and post-dialysis values probably represented total and bound folate, respectively. Urinary folate consisted almost exclusively of dialyzable or free folate. Folate in saliva, bile, and erythrocytes consisted of dialyzable and non-dialyzable fractions; gastric juice contained minimal amounts of folate.

In spite of low serum albumin in kwashiorkor the bound folate fraction was increased rather than decreased; in myeloma with hyperglobulinaemia there was no increase in the bound folate fraction. Nephrotic urine did not contain excess folate, but pregnancy urine (third trimester) showed increased total folate.

Serum, chromatographed on Sephadex G-25, produced two folate peaks, only the first $\overrightarrow{\bar{\sigma}}$ being associated with serum proteins. Urine contained only a second folate peak corresponding to the elution peak of pteroyl-monoglutamic acid (PGA). Adsorption studies with charcoal coated with 'molecular sieves' of varying size suggested that the predominant serum folate binder was of molecular weight $70,000-120,000$. It is unlikely to be albumin.

Serum is known to be a poor binder of pteroylmonoglutamic acid (PGA) (Condit and Grob, 1958; Hampers, Streiff, Nathan, Snyder, and Merrill, 1967; Metz, Zalŭsky, and Herbert, 1968) but serum binding of natural endogenous folate has been scantily studied (Markkanen, 1968).

We previously reported a non-dialyzable folate fraction present in serum but absent from urine (Retief and Huskisson, 1969). In the present study this non-dialyzable, and possibly proteinbound, folate fraction was further investigated.

\section{Methods}

Folate activity was measured microbiologically

${ }^{1}$ Present address: Faculty of Medicine, University of the OFS, Bloemfontein, RSA.

Received for publication 16 February 1970. with Lactobacillus casei by the aseptic addition technique of Herbert (1966). Serum and urine을 specimens obtained simultaneously from test $\rightarrow$ subjects were stored without preservative at $-20^{\circ} \mathrm{C}$; no demonstrable folate deterioration $\bar{N}$ occurred during our maximal storage time of ${ }^{\circ}$ three months. The $p \mathrm{H}$ of urine samples was 0 adjusted to 7.0 before storage.

Aliquots, each of 1 to $2 \mathrm{ml}$, of urine, serum, saliva, gastric juice, bile, and haemolyzed normalo whole blood (1 part blood: 9 parts distilled $\overparen{D}$ water) were dialyzed in Visking casing against $\stackrel{?}{?}$ $0.9 \% \mathrm{NaCl}$ in the dark at $4^{\circ} \mathrm{C}$ for 48 hours $D$ (Retief and Huskisson, 1969). Folate levels measured before and after dialysis were referred $\stackrel{\mathbb{P}}{\square}$ to as 'total folate' and 'bound folate', respectively. $\mathbb{\perp}$

Aliquots, each of 1 to $2 \mathrm{ml}$, of serum and urineo were agitated for five min. with $50 \mathrm{mg}$ pellets of various coated charcoal preparations (see below). The folate content of the supernatants (after 15 minutes centrifugation at $1,400 \mathrm{~g}$ ), were then $\frac{\bar{a}}{\overrightarrow{2}}$ 
compared with the initial folate level. Norit $\mathbf{A}^{\mathbf{1}}$ pharmaceutical grade neutral charcoal was coated with haemoglobin (Gottlieb, Lau, Wasserman, and Herbert, 1965), fibrinogen ${ }^{2}$, human gamma globulin ${ }^{3}$ or Dextraven ${ }^{4}$ by mixing it with these agents on a weight by weight basis: 5 parts charcoal to 1 part coating material (Herbert, 1969). Centrifuging $2 \mathrm{ml}$ of a $2.5 \%$ aqueous charcoal suspension produced a convenient 50 $\mathrm{mg}$ charcoal pellet, capable of adsorbing from serum more than $50 \mathrm{mg}$ free folate.

Aliquots, each of $2 \mathrm{ml}$, of normal and folatedeficient sera were incubated at $37^{\circ} \mathrm{C}$ for 30

${ }^{1}$ Amend Drug and Chem. Co., New York, USA

'Kabi, Stockholm, Sweden

'Serevac Laboratories, Cape Town, RSA

'Benger Laboratories, Cheshire, UK

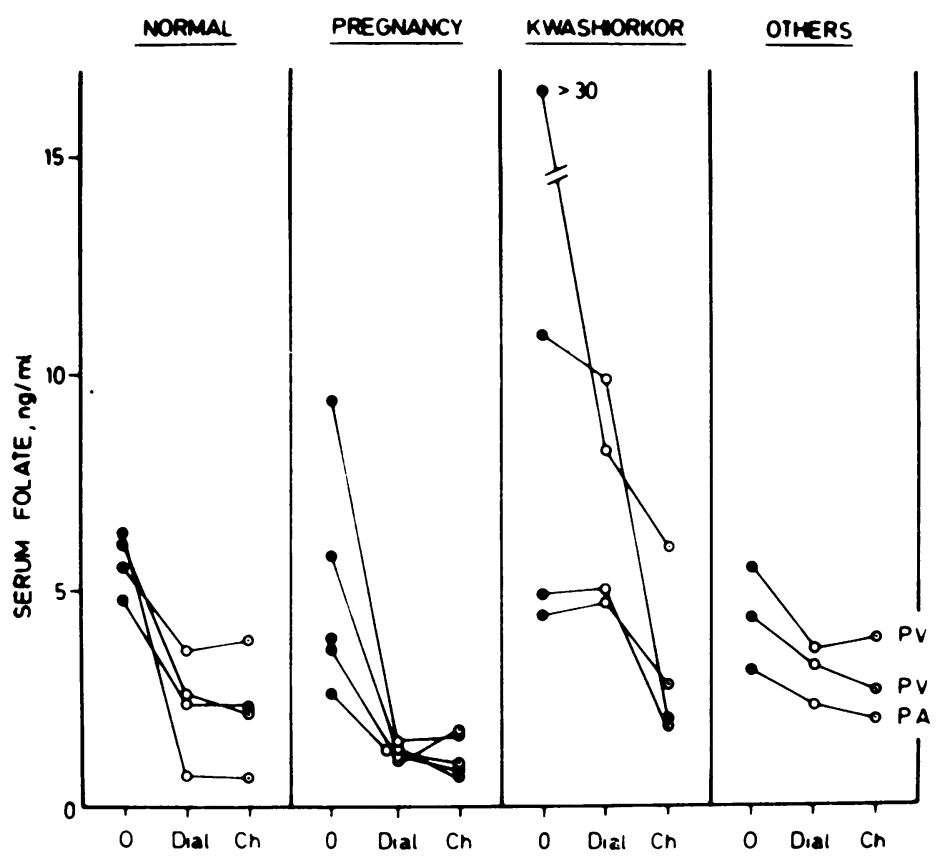

Fig. 1 A comparison between the serum folate clearing effect of $\mathbf{4 8}$ hours' dialysis and adsorption with haemoglobin-coated charcoal. $O=$ original serum folate; Dial = post-dialysis folate; $C h=$ folate after charcoal adsorption $P V=$ erythraemia $P A=$ pernicious anaemia min with varying amounts of added pteroylmonoglutamic acid (PGA) and N5-methyltetra-0 hydrofolic acid (methyl THF). (Methyl THF and PGA were assayed with $L$. case $i$ for biological activity and aqueous working solutions $(100 \mathrm{ng}) \overrightarrow{\vec{s}}$ of biologically active material per $\mathrm{ml}$ were usedo in the experiment.) After incubation, the serao were adsorbed with $50 \mathrm{mg}$ haemoglobin-coated" charcoal (see above), centrifuged, and the super- $-\vec{D}$ natant folate activity was measured.

Aliquots, each of $2 \mathrm{ml}$, of serum, urine, and $\mathrm{a}^{\infty}$ PGA solution (100 ng) were chromatographedo at room temperature on a Sephadex G-25 column $(30 \mathrm{~cm} \times 1.5 \mathrm{~cm})$. A phosphate buffero of $p H 6.1$ (similar to that used in the $L$. case assay) was used as elution medium, and passect through the column by hydrostatic pressure. Approximately $502 \mathrm{ml}$ aliquots were collected at a rate of $0.2 \mathrm{ml}$ per minute. Eluates were assayed for folate content and total protein waso determined as ultraviolet extinction at $280 \mathrm{~m} \mu$ in a Beckman DU spectrophotometer.

Preservatives such as ascorbic acid or mercap toethanol were not added to the samples, because Markkanen (1968) detected no significant folate sparing with these substances under very similar experimental conditions.

All glassware was autoclaved to ensure maxi? mal sterility and eluates were stored at $-20^{\circ} \mathrm{CO}$ until analysis could be performed.

\section{Results}

In Fig. 1 the effect of 48 hours' saline dialysis on serum folate is compared with folate clearances by haemoglobin-coated charcoal adsorption in certain clinical conditions.

In kwashiorkor less folate appeared to be los by dialysis than by charcoal adsorption, but in the other diseases residual folate was closely? comparable in the two methods.

Total and bound folate in serum and urine? measured before and after 48 hours' saline dialysis $>$ in a variety of conditions, are recorded in Table I을. In most conditions mean serum-bound folato fractions were comparable but kwashiorkor

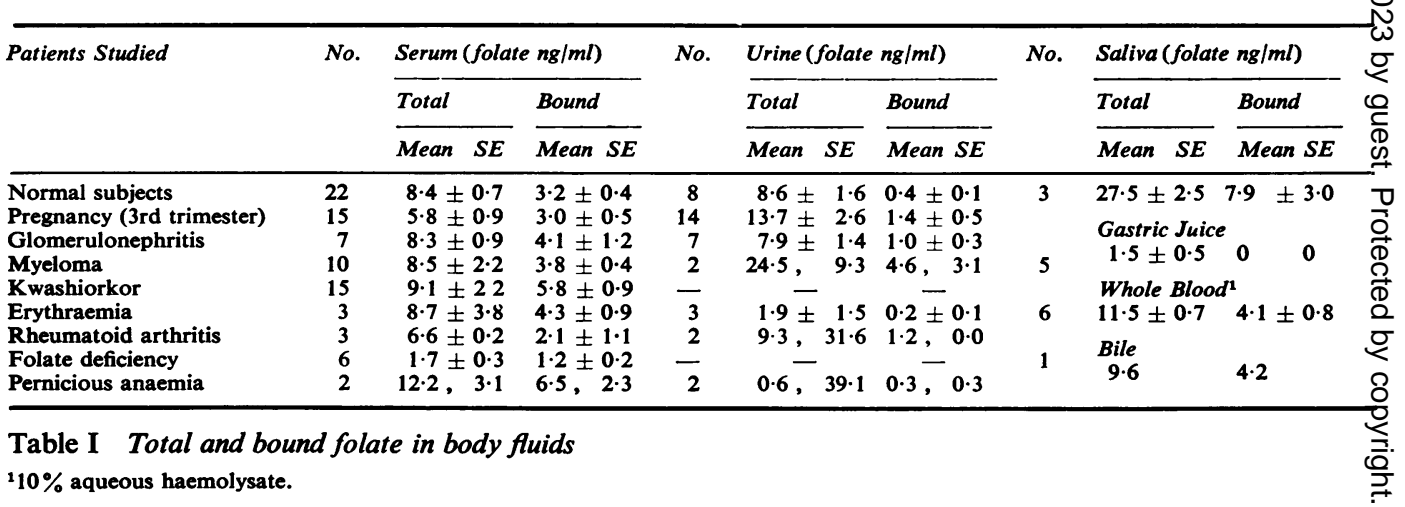




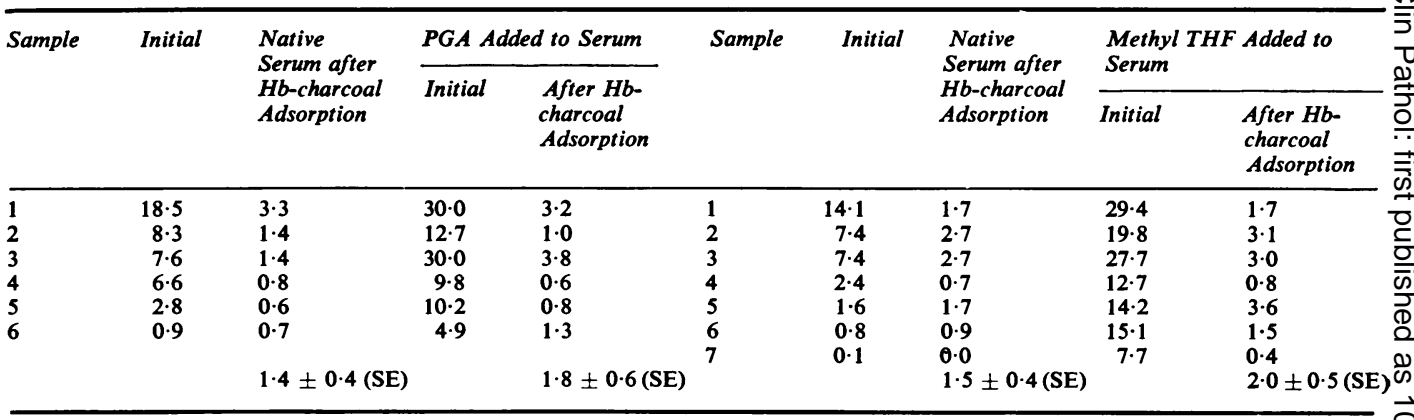

Table II Effect of excess PGA and methyl THF on folate binding by serum ${ }^{1}$

${ }^{1}$ Serum folate values expressed as $\mathrm{ng} / \mathrm{ml}$.

showed a moderately increased value. The mean serum protein and serum albumin values in kwashiorkor were $4.8( \pm 1.08) \mathrm{g} / 100 \mathrm{ml}$ and $1.67( \pm 0.27) \mathrm{g} / 100 \mathrm{ml}$, which are significantly lower than our mean values for normal adults, $7.05 \mathrm{~g} / 100 \mathrm{ml}$ and $4.15 \mathrm{~g} / 100 \mathrm{ml}$, respectively. The myeloma patients had mean total serum proteins of $8.7( \pm 0.9) \mathrm{g} / 100 \mathrm{ml}$ and mean gamma globulins of $3.46( \pm 1.13) \mathrm{g} / 100 \mathrm{ml}$ compared with our normal mean serum gamma globulin of $1.22 \mathrm{~g} / 100 \mathrm{ml}$ for adult patients. Bound folate thus appeared to be unrelated to serum albumin and gamma globulin.

Mean urinary folate was increased in the third trimester of pregnancy, compared with normal; the same group of pregnant patients had a mean serum level slightly less than normal. However, these were random urine values, and no attempt was made to calculate total daily urinary folate excretion. The pregnant patients were not on folate supplements. In spite of prominent proteinuria the glomerulonephritis group, which included a nephrotic patient, did not show significantly increased total or bound urinary folate fractions. Non-dialyzable folate was present in urine in very small amounts only, and could merely have represented residual folate contamination of the dialysis bags. Three saliva specimens examined had relatively high folate contents; most of the folate was dialyzable. Gastric juice contained very little folate; the values were not appreciably affected by previous neutralization of specimens to $p \mathrm{H} 7$. The folate present in whole blood, and in a single bile specimen contained non-dialyzable fractions, comparable with that of serum. Whole blood folate consists predominantly of red cell folate (Hoffbrand, Newcombe, and Mollin, 1966) so that the above findings are primarily representative of red cell folate.

When PGA and methyl THF were added to normal and folate-deficient sera and the sera subsequently adsorbed with haemoglobin-coated charcoal there was no significant binding of added folates in excess of the endogenous bound folate (Table II).

\begin{tabular}{|c|c|c|}
\hline \multirow[t]{2}{*}{ Adsorption Media } & \multicolumn{2}{|c|}{ Folate $(n g / m l)$} \\
\hline & Serum $A$ & Plasma $A$ \\
\hline $\begin{array}{l}\text { Nil } \\
\text { Uncoated charcoal } \\
\text { Charcoal + fibrinogen (MW 400,000) } \\
\text { Charcoal + gamma globulin } \\
\quad \text { (MW 155,000) } \\
\text { Charcoal + Dextraven (MW 120,000) } \\
\text { Charcoal + haemoglobin (MW 70,000) }\end{array}$ & $\begin{array}{r}12.9 \\
0.3 \\
0.4\end{array}$ & $\begin{array}{r}11 \cdot 3 \\
0.4 \\
0.4\end{array}$ \\
\hline
\end{tabular}

Table III Folate clearing effect of uncoated charcoal $\vec{\oplus}$ and a variety of coated charcoals ${ }^{1}$

'Serum and heparinized plasma were obtained from the same patient.

When serum and heparinized plasma from $a \stackrel{2}{\circ}$

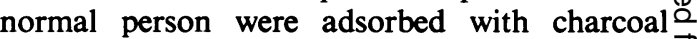
preparations coated with agents of varying molecular weight, folate was maximally cleared when the coating agent had a molecular weight of 155,000 or greater (Table III). A coat of molecular weight 70,000 (haemoglobin) resulted in folate clearing similar to that produced by: dialysis in Visking casing (Fig. 1). We did not 3 . experiment with charcoal coats of molecular weight less than 70,000. Dextraven-coated charcoal had a folate clearing efficiency midwayo between that of haemoglobin and gamma globulin, suggesting that the main folate bindero in serum (and plasma) may have a molecular weight between 70,000 and 120,000 .

Chromatography of serum on a Sephadex N G-25 column demonstrated two folate peaks, N the first eluting with the serum proteins and the second appearing later (Fig. 2). After haemoglobin-coated charcoal adsorption the second peak was largely abolished while the first re- $\stackrel{5}{+}$ mained unchanged. The first peak thus probably represents bound folate and the second peak free ${ }^{\circ}$ folate.

When normal urine was passed through the $\frac{}{\circ}$ column only a second folate peak was recorded, $\frac{\varrho}{\sigma}$ corresponding to the single elution peak of PGA (Fig. 3). Nephrotic urine gave a similar result 8 in spite of an associated protein peak.

Total folate recovery from the columns oftencō 
Serum

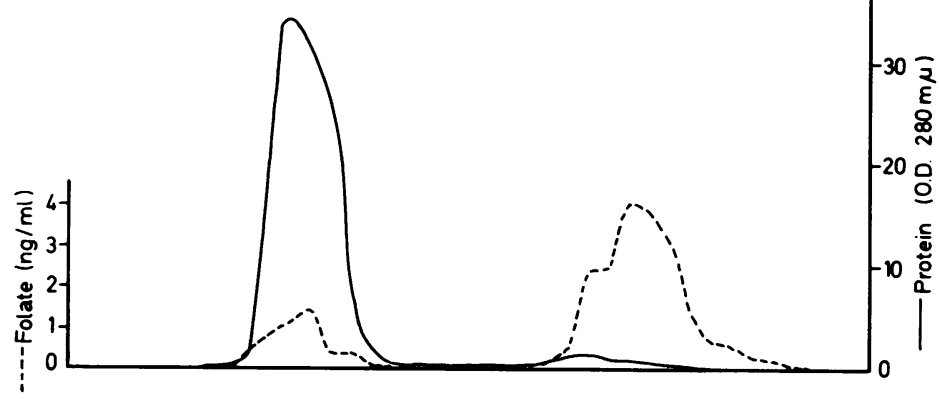

Serum after adsorption with $\mathrm{Hb}$-coated charcoal

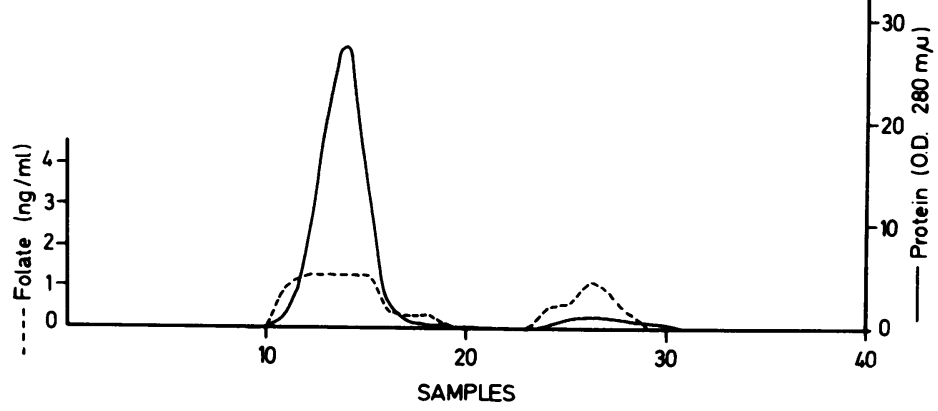

Fig. 2 Serum chromatography with Sephadex G-25.
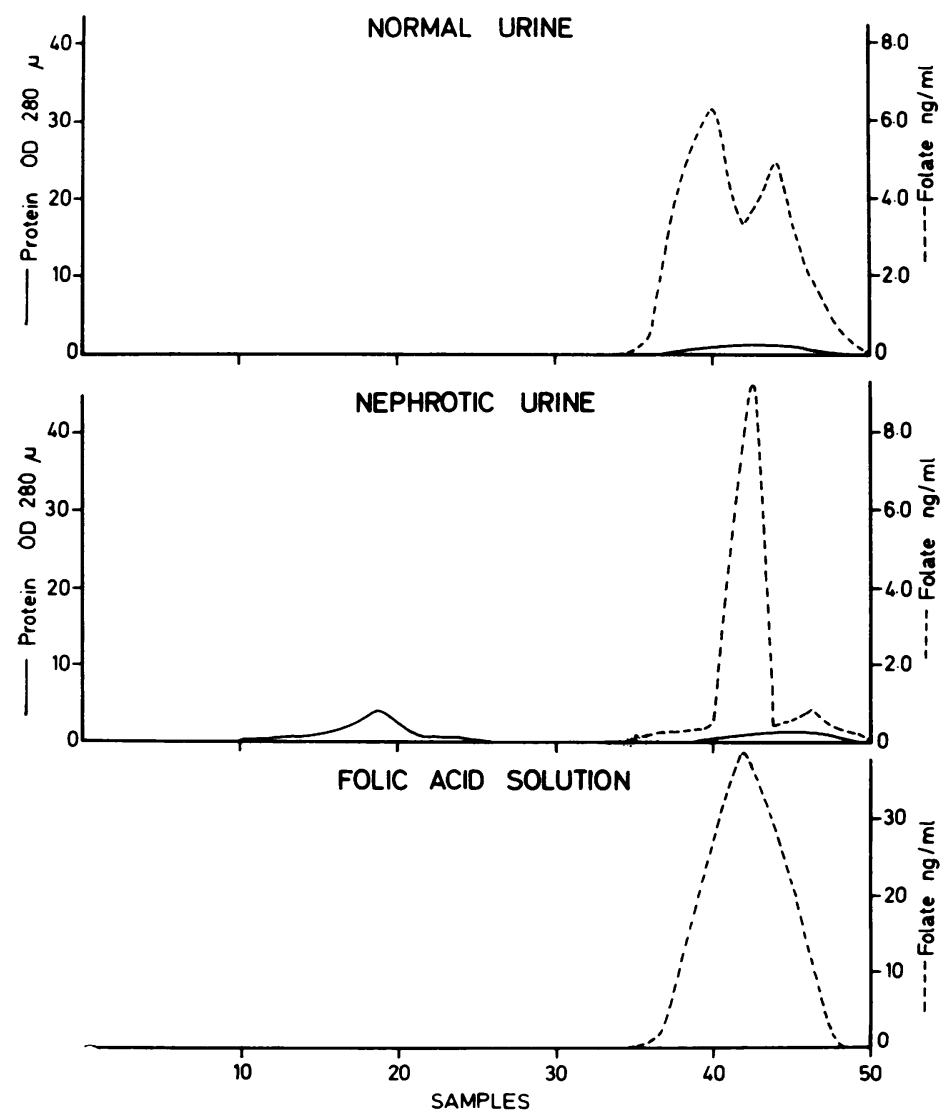

Fig. 3 Urine and PGA chromatography with Sephadex G-25. exceeded the folate applied as serum or urine. The reason for this is as yet obscure. However in a specific experiment the ratio between bound and total folate in the serum sample applied? usually compared well with the ratio between $\overrightarrow{{ }^{2}}$ protein-bound (first peak) folate and total folate? eluted. The serum applied in Fig. 2 had a bound folate fraction of $1.7 \mathrm{ng} / \mathrm{ml}$, with total folate o $10.3 \mathrm{ng} / \mathrm{ml}$ (ratio $16.5 \%$ ). After chromatography the first (bound) folate peak was $4.6 \mathrm{ng}$ and totap folate amounted to $30 \cdot 6 \mathrm{ng}$ (ratio $15 \cdot 0 \%$ ).

Electrophoresis and chemical analysis of the serum eluates associated with the second (nonprotein) folate peak revealed no demonstrablew protein in spite of a minimal ultraviolet light extinction at $280 \mathrm{~m} \mu$.

\section{Discussion}

These studies confirmed our previous findings (Retief and Huskisson, 1969) that serum folateo consists of a dialyzable and non-dialyzabled fraction. The non-dialyzable fraction is probablyo protein bound, eluting from the Sephadex G-25 column in association with the serum proteins $\overrightarrow{0}$ Adsorption of serum with haemoglobin-coateds charcoal had a folate clearing effect very similar to dialysis in Visking casing, suggesting that theo two techniques removed the same (free) folates fraction, and that the bond between folate anc binder is a significant one. Charcoal preparations $\frac{O}{D}$ coated with molecules of varying size, may be used to estimate the molecular size of binder $\overrightarrow{\overrightarrow{0}}$ substances (Herbert, 1969). With this procedure the shape of coating molecules must of course also be taken into account. Such an experimen? was performed and it suggested that the maim serum folate binder may have a moleculas weight between 70,000 and 120,000 . It is unlikelpe. to be albumin as kwashiorkor (characterized by? a markedly decreased serum albumin) showed an increased rather than decreased bound folates fraction. Serum vitamin $\mathbf{B}_{12}$ binding capacity is also increased in kwashiorkor in contrast witlp most other binding proteins (Grassmann an Retief, 1969). Glomerulonephritic urine, witlp prominent albuminuria, did not contain increased amounts of total or bound folate. Markkanenv (1968) performed serum gel filtration with Sephadex G-200 and recorded two protein associated folate peaks: a small peak in the 900,000 molecular weight range and a largep fraction in the 70-90,000 molecular weight range In this article he refers to 'PGA binders' but iह is evident from the text that naturally occurring L. case $i$ activity was in fact measured. As we $\operatorname{did}_{D^{+}}$ Markkanen (1968) found prominent folate elu음 tion distal to the protein peak, although pro? longed dialysis was in his experience less effective in clearing this peak.

Folate recovery from our Sephadex colum 
was often in excess of $100 \%$. One wondered whether elimination of serum folate antagonists (Cowan, Hoffbrand, and Mollin, 1966) during the chromatography procedure might have been partially responsible for this phenomenon.

We were unable to demonstrate unsaturated folate-binding capacity in normal and folatedeficient sera after the addition of PGA and methyl THF (Table II). The physiological significance of the free and bound folate fractions in serum is unknown, but urinary folate may derive from the free serum folate fraction. However, there was no constant relationship between free serum folate and urinary folate; in pregnancy the mean urinary folate was increased in spite of a decreased mean free serum folate (Table I). Bound folate was not found in urine in significant amounts except in two myeloma urines tested. The trace values recorded in Table I could represent residual contamination of the dialysis bags, and chromatography of urine did not reveal an early folate peak. In a limited study of other clinical conditions there was little significant difference as far as the free: total serum folate ratio was concerned (Table $I$ ). We are further investigating the finding in kwashiorkor that membrane dialysis gave higher bound serum folate values than did coated charcoal adsorption.

We wish to thank Professor A. J. Brink, Department of Internal Medicine, for supplying research facilities, and Professor A. van Zyl, Department of Pharmacology, for assistance with chromatography procedures.
The project was supported by the South African Council for Scientific and Industrial Research.

Professor Victor Herbert, Mount Sinai School of Medicine, New York, USA, kindly supplied N5-methyltetrahydrofolic acid.

References

Condit, P. T and Grob D. (1958). Studies on the folic acid vitamins. 1. Observations on the metabolism of folic acid in. man and on the effect of aminopterin. Cancer (Philad.), $\overrightarrow{-}$ $11,525-536$.

Cowan, J. D., Hoffbrand, A. V., and Mollin, D. L. (1966). Effect of serum factors other than folate on the Lacto $\overrightarrow{0}$
bacillus casei assay. Lancet, 1, 11-14.

Gottlieb, C., Lau, K. S., Wasserman, L. R., and Herbert, V. N (1965). Rapid charcoal assay for intrinsic factor (1F) $\omega$ gastric juice unsaturated $B_{12}$ binding capacity, antibody $\infty$ to $1 \mathrm{~F}$, and serum unsaturated $B_{12}$ binding capacity. Blood, 25, 875-884.

Grassmann, R., and Retief, F. P. (1969). Serum vitamin-B ${ }_{1-}$ binding proteins in kwashiorkor. Brit. J. Haemat., 17, 237-243.

Hampers, C. L., Streiff, R., Nathan, D. C., Snyder, D., and Merrill, J. P. (1967). Megaloblastic hemacopoiesis in uremia and in $O$ patients on long-term hemodialysis. New Engl. J. Med., \ 276, 551-554.

Herbert, V. (1966). Aseptic addition method for Lactobacillus casei assay of folate activity in human serum. J. clin. $\mathbb{D}$ Path., 19, $12-16$.

Herbert, V. (1969). Coated charcoal separation of free labelled $\vec{\theta}$ hormone from hormone bound to antibody. In Protein and Polypoptide Hormones. (Excerpta med. int Cong. Ser.), Excerpta Medica, Amsterdam, 161, pp 55-60.

Hoffbrand, A. V., Newcombe, B. F. A., and Mollin, D. L. (1966). Method of assay of red cell folate activity and $t$ he value of the assay as a test for folate deficiency. J. clin. Path., 19, 17-28.

Markkanen, T. (1968). Pteroylglutamic acid (PGA) activity of serum in gel. filtration. Life Sci., 7, 887-895.

Metz, J., Zalǔsky, R., and Herbert, V. (1968). Folic acid binding by serum and milk. Amer. J. clin. Nutr., 21, 289-297.

Retief, F. P., and Huskisson, Y. J. (1969). Serum and urinary folate in liver disease. Brit. med. J., 2, 150-153. 